\title{
Bleaching corals of two species appear to feed from neighboring algal turfs
}
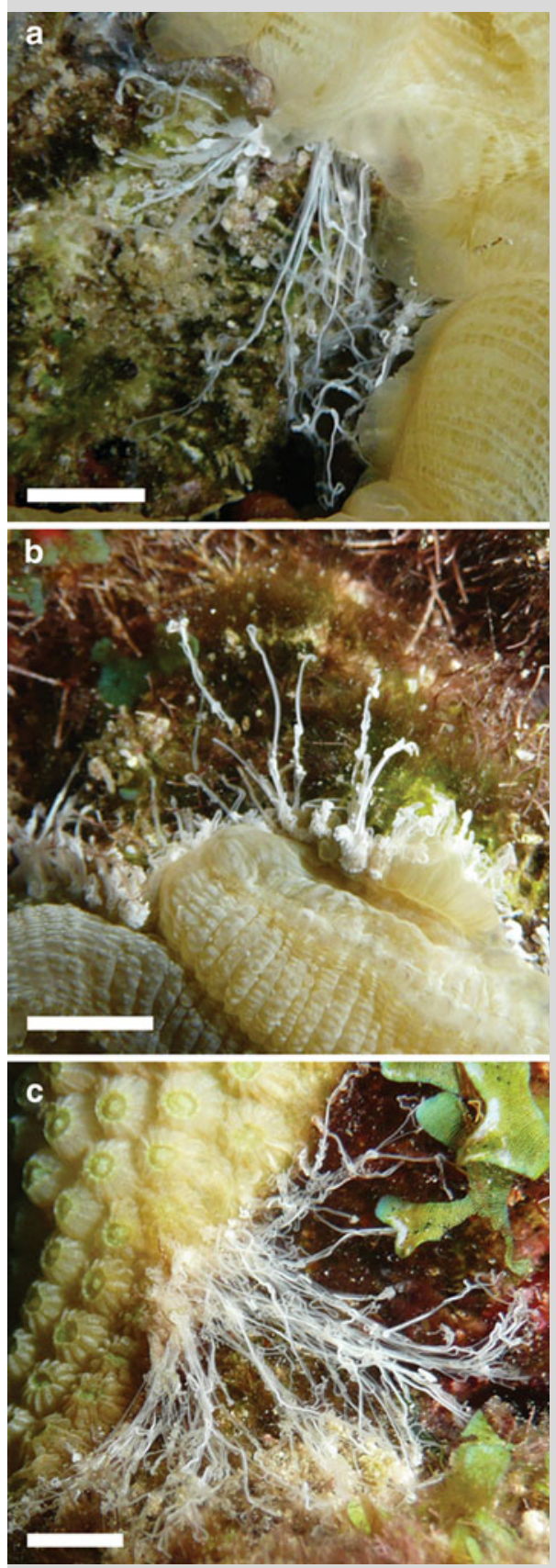

Fig. 1 Partially bleached corals with mesenterial filaments extended into nearby algal turfs. a and b Colpophyllia natans. c Montastraea faveolata. A small number of interactions with branching macroalgae (Dictyota sp.) are also visible in (b) and (c). All scale bars are approximately $0.5 \mathrm{~cm}$
During bleaching, corals typically cannot obtain sufficient energy from their symbiotic dinoflagellates alone and must therefore rely on alternative energy sources such as plankton, lipid reserves (e.g., Grottoli et al. 2004), and photosynthate from endolithic algae (Fine and Loya 2002). Another possible strategy for energy acquisition during bleaching is described here. On three consecutive nights in October 2010, five heavily bleached colonies of Colpophyllia natans were observed extending their mesenterial filaments from the colony edge into neighboring algal turfs up to $4 \mathrm{~cm}$ away (Fig. 1a, b). The same behavior was observed in one bleaching colony of Montastraea faveolata (Fig. 1c). All observations were made between 20:00 and 23:00 h at depths of 7-9 m. Mesenteries were observed interacting only with algal turfs and occasionally with larger fragments of macroalgae (Fig. 1a, c), but not with neighboring corals or bare substrate.

Turf algae are known to exude glucose and other photosynthetic products from their tissues (Haas et al. 2010). The bleaching corals may have used their extended mesenteries to feed on this photosynthate, on the diatoms, microalgae, and heterotrophic bacteria shown to be associated with the macroalgae at this same study site (Barott et al. 2011), and/or on the microfauna sheltered within the turfs. Colpophyllia natans is known to fight neighboring corals using its relatively long mesenterial filaments; however, neither $C$. natans nor $M$. faveolata is known to "fight" algal turfs. Furthermore, this behavior was observed only during an extended coral bleaching event and never in 30 preceding hours of nighttime observation or $100+$ total hours of observation at this site (Water Factory, Curaçao, $\left.12^{\circ} 10^{\prime} 91^{\prime \prime} \mathrm{N}, 68^{\circ} 95^{\prime} 49^{\prime \prime} \mathrm{W}\right)$. Thus, the behavior described here is most likely a feeding strategy used by corals undergoing an extended period of bleaching. Because most research on coral bleaching is conducted during the day, the generality of this behavior is not known. More broadly, this observation highlights the fact that simultaneous changes to reef health and community structure (such as more frequent coral bleaching events and long-term increases in turf algal cover) may occur for different reasons and at different rates but may nevertheless act together to reveal previously unknown acclimatization behaviors in coral reef organisms.

\section{References}

Barott KL, Rodriguez-Brito B, Janouškovec J, Marhaver KL, Smith JE, Keeling P, Rohwer FL (2011) Microbial diversity associated with four functional groups of benthic reef algae and the reef-building coral Montastraea annularis. Environ Microbiol 13:1192-1204

Fine M, Loya Y (2002) Endolithic algae: An alternative source of photoassimilates during coral bleaching. Proc R Soc B-Biol Sci 269:1205-1210

Grottoli AG, Rodrigues LJ, Juarez C (2004) Lipids and stable carbon isotopes in two species of Hawaiian corals, Porites compressa and Montipora verrucosa, following a bleaching event. Mar Biol 145:621-631

Haas AF, Jantzen C, Nauman MS, Iglesias-Prieto R, Wild C (2010) Organic matter release by the dominant primary producers in a Caribbean reef lagoon: implication for in situ oxygen availability. Mar Ecol Prog Ser 409:27-39

K. L. Marhaver ( $\bowtie)$

School of Natural Sciences, University of California at Merced, Merced, CA, USA

e-mail: kmarhaver@ucmerced.edu

K. L. Marhaver

CARMABI Foundation, Piscaderabaai Z/N, Willemstad, Curaçao

Received: 10 April 2011/Accepted: 11 May 2011/Published online: 17 June 2011

Coral Reefs (2011) 30:651

(C) Springer-Verlag 2011 